\title{
Indonesia's Defense Industry: Influences of TQM Practices on Employee Productivity with the Mediating Role of Job Satisfaction
}

\author{
Nunung Kristiana ${ }^{1, *}$ Risna Wijayanti ${ }^{2}$, Djumilah Hadiwidjojo ${ }^{3}$ \\ 1,2,3 Faculty of Economic and Business, Universitas Brawijaya, Indonesia \\ *Corresponding author. Email: nuna.c631@gmail.com
}

\begin{abstract}
This study examined the effects of TQM practices on employee productivity mediated by job satisfaction in Indonesia's defense industry using PT Pindad as an example. High employee productivity reflects sought-after product quality - a crucial, desired aspect in this industry, considering that the product's function is closely related to human life. For business entities, such productivity is vital because it is part of the internal economic affairs of a company that shapes the profitability measure. The study also measured the mediating effect of Job Satisfaction (Z) in the causal relationship between TQM Practices (X) and Employee Productivity (Y). For this purpose, questionnaires were distributed to 160 permanent employees. Then, partial least squares (PLS) were employed to test the proposed hypotheses. The results showed that variable Z (Job Satisfaction) mediated the effect of variable X (TQM Practices) on variable Y (Employee Productivity), with a p-value $=0.004<0.05$. Further, variable X (TQM Practices) significantly affects variable $\mathrm{Y}$ (Employee Productivity) and variable Z (Job Satisfaction), as evident from their respective p-values $(0.000<0.05)$.
\end{abstract}

Keywords: Employee Productivity, Job Satisfaction, TQM Practice, Defense Industry.

\section{INTRODUCTION}

Nowadays, productivity is part of a company's internal economic affairs functioning as a profitability measure. Profitability is a factor that differentiates a company from its competitors in terms of performance. A company's productivity and, thus, profitability partially depend on employee productivity, which is defined as a representation of job performance, including the individual's ability to complete work tasks by drawing on necessary skills, experience, attitudes, and motivation to implement meaningful behaviors and actions for an organization [1]. There was a downward trend in labor productivity growth in Indonesia from 2015 (4.70\%) to $2019(3.00 \%)$ [2]. Such low productivity can be primarily attributed to low-quality human resources [3] and management's insufficient understanding of variations in performance, including employee performance [4].

Total quality management (TQM) provides an excellent opportunity to improve employee productivity. In theory, to achieve this goal, it positively affects employees by increasing their commitment, effectiveness, and performance efficiency [4] [5] [6] [7]. Some of these dimensions are conceptually identified as aspects directly impacting employee productivity, including Leadership, Employee Empowerment, Training, Teamwork, Reward, and Recognition [8].

Furthermore, in most cases, management strategy using the most well-known TQM practice proves effective in promoting job satisfaction $[9,10]$. Job satisfaction is an emotional reaction or response of employees to their work value, which is a function of the perceived relationship between what they want from their job and what they feel about it [11]. Job satisfaction is mainly considered a phenomenon in which job characteristics match the employee's demands, creating a feeling of fulfillment derived from the job. Therefore, it underpins employee loyalty, continuity, interest, and productivity and can be seen as a positive emotional reaction to a particular work $[9,10]$. 


\section{LITERATURE REVIEW AND HYPOTHESIS DEVELOPMENT}

The factors determining employee productivity levels are employee quality [3] and management's understanding of variations in employee performance [4]. Most variations in work are commonly caused by or related to the system, which is perceived as the source of performance both indirectly and interactively [4]. It is logical for workers to understand that performance may vary due to system factors that are beyond their control. Therefore, it is necessary to establish a better concept for the system to improve employee competence, commitment, and, finally, employee productivity.

Operations management is a process that involves planning, organizing, managing, controlling, and supervising production and manufacturing processes [12], interlinks different inputs (resources), outputs (goods), and processes.

Figure 1 shows employees (people) as the system input, representing the position of employee productivity in operations management. This concept corresponds to the TQM theory, which describes that overall organizational quality starts with inputincluding employees, followed by process and output [13].

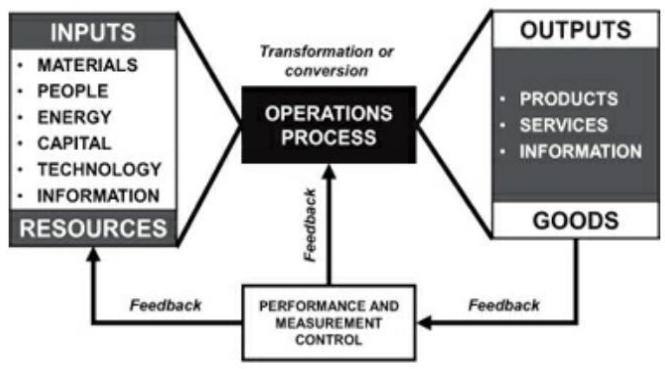

Figure 1. Illustration of an operation system [12]

With regard to people and TQM, another factor that affects employee productivity is job satisfaction. The most crucial aspect of job satisfaction is work performance. TQM helps employees develop and utilize their full potential—due to which job satisfaction is most likely to be achieved-to ultimately reach company's business goals $[9,14]$.

\subsection{Effect of TQM Practice on Employee Productivity}

TQM practices are considered the key to influencing employee performance in any organization. Waldman [4] adds that TQM practices is very helpful in providing rules and regulations and can improve employee performance in terms of effectiveness, efficiency, and organizational productivity.

Powel [15] also stated that in 1949 the Union of Japanese Scientists and Engineers (JUSE) formed a committee that gave birth to TQM under the influence of Deming and Juran to increase Japanese manufacturing productivity. In its development, scholars have found a positive relationship between TQM practices and employee productivity $[7,16]$. However, wide gaps about the effect of TQM practice on employee productivity remain as the results of some empirical research are only partly significant, while several others are insignificant. Therefore, this study was intended to determine the relationship between TQM practices and employee productivity. Accordingly, the following hypothesis was formulated:

H1: TQM practice has a significant positive effect on employee productivity.

\subsection{Influence of TQM Practice on Job Satisfaction}

Job satisfaction is defined as an emotional reaction that values a worker's response to his/her job, which is a function of the perceived relationship between what the worker wants from the job and what he/she feels about it [11]. Factors that determine job satisfaction include financial benefits, career growth and promotion, workplace environment, supervisors, and colleagues [10], which are dimensions of TQM Practices. Even though several previous studies have also shown and confirmed the effect of TQM practices on job satisfaction [i.e., 9, $10,11,14,17]$, their results are inconsistent. Therefore, this study was intended to determine the relationship between TQM practices and job satisfaction. In light of that, the following hypothesized was proposed:

H2: TQM practices have a significant positive effect on job satisfaction.

\subsection{Effect of TQM Practices on Employee Productivity Mediated by Job Satisfaction}

TQM practices positively affect employees by increasing their satisfaction and commitment, which improve the effectiveness and efficiency of their performance and, eventually, organizational productivity [4] [5] [6] [7]. 
Many previous studies have examined the effect of TQM on job satisfaction [18] [19] and described the correlation between job satisfaction and employee productivity, with job satisfaction as one of the independent variables that significantly influence the dependent variable, employee productivity [20] [21] [22]. In addition, based on the results of the literature review, this study aimed to determine the relationship between TQM practices, employee productivity, and job satisfaction, which is hypothesized as follows:

H3: TQM practices, mediated by job satisfaction, have a significant positive effect on employee productivity.

\section{METHOD}

\subsection{Sampling}

This study used an explanatory research design. At the first stage, the human resource manager at PT Pindad was initially contacted by phone to explain the research objectives and inquire about a necessary research permit. Then, a survey was conducted to gather data from respondents using a questionnaire as the primary tool. This questionnaire was directly distributed (offline) by visiting each of the 160 respondents - i.e., permanent employees with stratum 4 to 5 at PT Pindad in Turen, Indonesia. The demographic distribution of the respondents is presented in Table 1.

Table 1. Demographic Distribution of the Research Respondents

\begin{tabular}{llcc}
\hline Characteristics & Categories & Freq. & Percentage \\
\hline Age & $<40$ y.o. & 128 & 80 \\
& $>40$ y.o. & 32 & 20 \\
Gender & Female & 43 & 27 \\
& Male & 117 & 73 \\
Length of & $<3$ years & 8 & 5 \\
tenure & 3-10 years & 100 & 63 \\
& $>10$ years & 52 & 32 \\
& Senior & & \\
Educational & High & 96 & 60 \\
achievement & School & & \\
& Associate & 16 & 10 \\
& Degree & & \\
& Bachelor's & 48 & 30 \\
& Degree & & \\
\hline
\end{tabular}

\subsection{Measures}

Responses to each questionnaire item (research instrument) were measured with a five-point Likert scale: strongly disagree $(\mathrm{SD}=1)$, disagree $(\mathrm{D}=2)$, neutral $(\mathrm{N}=3)$, agree $(\mathrm{A}=4)$ and strongly agree (SA = 5). Employee productivity (Y) was measured using two indicators: Task Performance adopted from Zeglat and Suzi [1] and Contextual Performance from Koopman et al. [23]. As for the TQM practices $(\mathrm{X})$, this variable was measured with five indicators: Leadership [24], Employee Empowerment [9], Training [9], Teamwork [25], and Rewards and Recognition [25]. Furthermore, to measure Job Satisfaction (Z), six indicators were used, namely Supervisors [26], Promotion and Career Advancement Opportunities [24], Equitable Rewards [26], Work and Environment [24], Job Participation [27], and Co-workers [26].

\subsection{Data Analysis}

Partial least square-based structural equation modeling (PLS-SEM) was employed to estimate the relationship between latent variables in the observed concept, calculate the indicator values of all variables, and build a vast and complex outer (or measurement) and inner (structural) model [28]. The three research hypotheses were tested after confirming the measurement model's convergent validity and discriminant validity on each indicator of the three constructs. The goodness-of-fit testing aimed to evaluate the feasibility of the statistical model by identifying the values of $\mathrm{R}$-squared $\left(\mathrm{R}^{2}\right)$ and the predictive relevance $\mathrm{Q}^{2}$ to assess the extent to which the observed score matched with the one expected/modeled using the predefined parameters [28]. Furthermore, bootstrapping was used to test the mediating effect of job satisfaction in the PLS method [29].

\section{RESULT}

\subsection{Measurement Model}

The measurement model derived through PLSSEM was analyzed to determine the validity and reliability of a construct. Two tests were used to evaluate its construct validity, including convergent validity and discriminant validity. First, the convergent validity was assessed by observing the factor loading value of each item [30]. Second, the discriminant validity was calculated by observing each variable's average variance extracted (AVE), the test results shown in Table 3. Third, the construct validity was interpreted from the discriminant validity (Fornell-Larcker criterion). The test results shown in Table 4 indicate that the square roots met 
the requirements for discriminant validity. Thus, combined with the convergent validity, this result means that all items of each variable actually measure the latent variable that corresponds to the indicator (evidence for construct validity).

Table 3. Discriminant Validity (AVE) of the Research Variables

\begin{tabular}{lcc}
\hline \multicolumn{1}{c}{ Variables } & $\begin{array}{r}\text { Average Variance } \\
\text { Extracted } \\
\text { (AVE) }\end{array}$ & Conclusion \\
\hline X (TQM Practices) & 0.600 & Valid \\
Z (Job & 0.573 & Valid \\
Satisfaction) & & \\
Y (Employee & 0.581 & Valid \\
Productivity) & & \\
\hline
\end{tabular}

Table 4. Discriminant Validity of the Research Variables Using the Fornell-Larcker Criterion

\begin{tabular}{lcccc}
\hline \multicolumn{1}{c}{ Variabel } & $\mathrm{X}$ & $\mathrm{Z}$ & $\mathrm{Y}$ & Conclusion \\
& & & & \\
\hline $\begin{array}{l}\mathrm{X} \text { (TQM } \\
\text { Practice) }\end{array}$ & 0.775 & & & Valid \\
$\begin{array}{l}\text { Z (Job } \\
\text { Satisfaction) } \\
\text { Y (Employee } \\
\text { Productivity) }\end{array}$ & 0.519 & 0.757 & & Valid \\
\hline
\end{tabular}

Furthermore, the measurement model was evaluated for its reliability. Each construct is categorized into reliable with a composite reliability coefficient of higher than 0.700 [28] and Cronbach's alpha exceeding 0.600 [29]. Table 5 summarizes the composite reliability and Cronbach's alpha calculation results.

Table 5. Composite Reliability and Cronbach's Alpha of the Research Variables

\begin{tabular}{lccc}
\hline \multicolumn{1}{c}{ Variables } & $\begin{array}{c}\text { Cronbach's } \\
\text { Alpha }\end{array}$ & $\begin{array}{c}\text { Composite } \\
\text { Reliability }\end{array}$ & Conclusion \\
\hline $\begin{array}{l}\text { X (TQM } \\
\text { Practices) }\end{array}$ & 0.963 & 0.966 & Reliable \\
$\begin{array}{l}\text { Z (Job } \\
\text { Satisfaction) }\end{array}$ & 0.964 & 0.967 & Reliable \\
$\begin{array}{l}\text { Y (Employee } \\
\text { Productivity) }\end{array}$ & 0.955 & 0.959 & Reliable \\
\hline
\end{tabular}

\subsection{Structural Model}

Testing of structural model aims to evaluate its accuracy (goodness of fit) in a conceptual research framework. In PLS analysis, R-squared $\left(\mathrm{R}^{2}\right)$ and predictive relevance $\left(\mathrm{Q}^{2}\right)$ are goodness-of-fit measures, where a $\mathrm{Q}^{2}$ close to 1 indicates a good fit (Hair et al., 2017). Table 5 summarizes the $\mathrm{R}^{2}$ and $\mathrm{Q}^{2}$ of the model. It shows that variable $\mathrm{X}$ can explain $27 \%$ of $\mathrm{Z}$ and $44.7 \%$ of $\mathrm{Y}$ variance, while the remaining $73.0 \%$ and $53.0 \%$ variance are the contributions of other variables not included in the research scope. The derived Q-squared (0.596) indicates that the model can explain $59.6 \%$ of the diversity of data.

Table 5. $\mathrm{R}^{2}$ and $\mathrm{Q}^{2}$ of the Built Model for Variables

\begin{tabular}{lc}
\multicolumn{1}{c}{ Z and Y } \\
\hline Variables & $\mathbf{R}^{2}$ \\
Y (Job Satisfaction) & 0.270 \\
& 0.447 \\
$\mathrm{Q}^{2}=1-\left(1-\mathrm{R} 1^{2}\right) \times\left(1-\mathrm{R} 2^{2}\right)$ & \\
$\mathrm{Q}^{2}=1-(1-0.270) \times(1-0.447)$ & \\
$\mathrm{Q}^{2}=0.596$
\end{tabular}

Afterward, the total coefficient of determination ( $\mathrm{R}^{2}$ of Job Satisfaction and Employee Productivity) was multiplied by its communality (AVE) to produce the goodness-of-fit value (GoF). The calculation below resulted in a GoF of 0.455 . This figure means that the model has high accuracy $(>0.36)$ [31].

GoF $=\sum \sqrt{\overline{\text { Communality }} \times \overline{R^{2}}}$

(1)

GoF $=\sqrt{\left(\frac{0.573+0.581}{2}\right) \times\left(\frac{0.270+0.447}{2}\right)}$

(2)

GoF $=\sqrt{0.577 \times 0.359}=0.455$

(3)

\subsection{Hypothesis Testing}

The research hypotheses were tested statistically. An effect is deemed significant if the p-value is less than 0.05 or insignificant if it is the contrary. Figure 2 shows the path diagram in which Employee Productivity is shaped directly by TQM Practices and indirectly by the mediating role of Job Satisfaction. Referring to the model, the study examined three hypotheses with a criterion, i.e., the t-statistic must be greater than the critical value (1.96). Table 6 shows the hypothesis testing results in SmartPLS software.

Table 6. Hypothesis testing of the structural model using partial least squares

\begin{tabular}{lcccl}
\hline Hyphoteses & $\begin{array}{c}\text { Path } \\
\text { Coefficient } \\
(\beta)\end{array}$ & $\begin{array}{c}\mathrm{t}- \\
\text { statistic }\end{array}$ & $\begin{array}{c}\mathrm{p}- \\
\text { values }\end{array}$ & Conclusion \\
\hline $\mathrm{H} 1: \mathrm{X} \rightarrow \mathrm{Y}$ & 0.517 & 8.779 & 0.000 & Accepted \\
$\mathrm{H} 2: \mathrm{X} \rightarrow \mathrm{Z}$ & 0.519 & 7.315 & 0.000 & Accepted \\
$\mathrm{H} 3: \mathrm{X} \rightarrow \mathrm{Z}$ & & & & \\
$\rightarrow \mathrm{Y}$ & 0.121 & 2.886 & 0.004 & Accepted \\
\hline
\end{tabular}




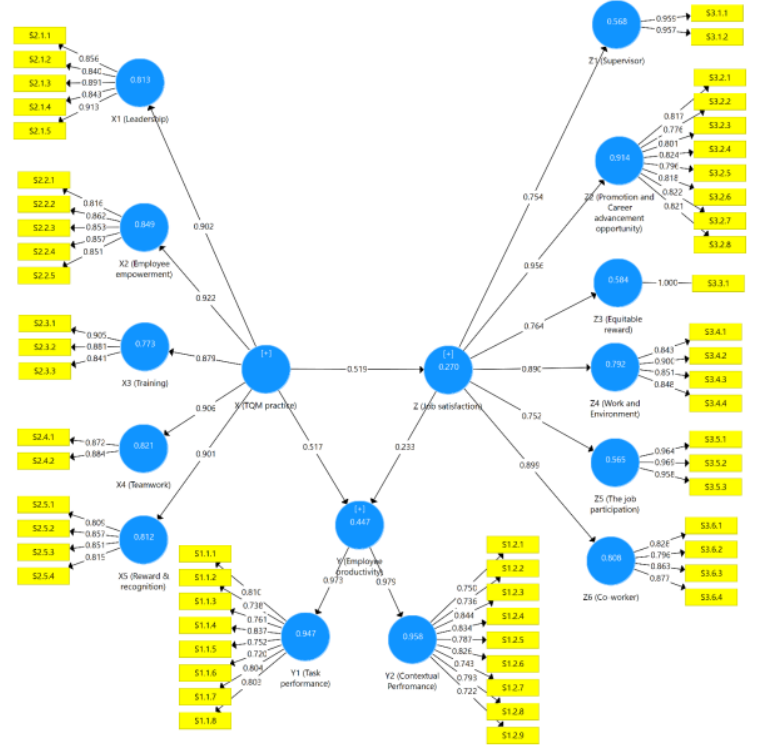

Figure 2. Structural model correlating Employee Productivity with TQM Practices and Job Satisfaction generated using partial least squares

\section{DISCUSSION}

\subsection{Effect of TQM Practices on Employee Productivity}

The results showed a t-statistic higher than the critical value $(8.779>1.96)$, with a p-value of 0.000 $<0.05$, supporting the empirical studies by Iqbal [7] and Putri et al. [16], which found that the variable TQM Practices has a significant positive effect on Employee Productivity. Therefore, it can be inferred that a slight change in the implementation of TQM practices will substantially affect employee productivity.

TQM practices provide management and employees with the knowledge and skills to build, improve, and manage a total quality approach. The indicators of TQM Practices in this study represent the best way to provide employees with information, knowledge, cooperation, strength, and rewards to make them more skilled, committed, and productive. Further, adopting the principles of TQM is believed to inspire them to grow and succeed, leading to increased productivity. In this case, enhancing the quality of products, services, employees, and processes is a strategy to improve organizational competitiveness [13].

\subsection{Effect of TQM Practices on Job Satisfaction}

Many factors influence job satisfaction, for example, financial and non-financial benefits, career growth and promotion, workplace environment, and supervisors and colleagues; all of which are included in TQM [10]. An ineffective TQM program will make employees less motivated or dissatisfied and, eventually, reduce productivity. The extent to which TQM practices are effectively implemented in a company significantly affects changes in labor productivity [16]. According to the synergy theory and social exchange theory, successful teamwork increases employees' efficiency and effectiveness [17] and job satisfaction [9]. Appropriate education and training not only increase their satisfaction [10] and performance but also reflect the organization's commitment to assisting their career growth [32]. Moreover, if good works are rewarded financially and non-financially, it will motivate employees and increase their level of satisfaction [17].

This study revealed that, in the case of Pindad, the variable TQM Practices has significant positive effects on Job Satisfaction with a t-statistic higher than the critical value $(7.315>1.96)$ and a p-value of $0.000<0.05$. These results support empirical studies by Ahmed and Idris [32], Minjoon et al. [9], and Kabak et al. [10], which found that TQM practices significantly and positively affect job satisfaction.

\subsection{The Mediating Role of Job Satisfaction in The Effect of TQM Practices on Employee Productivity}

Job satisfaction occurs if the workplace aspects that motivate an employee are fulfilled. It has been reported that TQM practices influence job satisfaction $[9,10,32]$ and that job satisfaction affects employee productivity [20, 21, 22]. In detail, TQM practices positively impact employee productivity by increasing employee satisfaction; satisfaction and commitment determine to what extent employees perform effectively and efficiently-these are predictors of employee productivity [4, 5, 6, 7]. The indirect effect of variable $\mathrm{X}$ (TQM Practices) on $\mathrm{Y}$ (Employee Productivity) through Z (Job Satisfaction) was also tested as a hypothesis in this study. The results showed a path coefficient $(\beta)$ of 0.121 , with a $p$-value of $0.004<0.05$ (significant), meaning that $\mathrm{Z}$ (Job Satisfaction) is a mediating variable that explains the 
effect of variable $\mathrm{X}$ (TQM Practices) on $\mathrm{Y}$ (Employee Productivity).

\section{CONCLUSION}

Based on the research results, Pindad's management needs to evaluate and improve the implementation of TQM practices by focusing on creating training programs that are more systematically targeted to augment employee competencies and on enhancing the reward system, especially in career development programs.

\section{LIMITATIONS}

This study has several drawbacks that need to be refined for future studies. First, the primary data were collected from 160 employees of PT Pindad with stratum 4 and 5 . Thus, future research can verify the obtained information from respondents of all strata. Second, to explain TQM practices as a variable, this study only focused on five indicators directly related to employees. Other indicators that shape TQM practices can be included in future research to find more evidence and further explore how TQM practices develop in organizations.

\section{AUTHORS CONTRIBUTIONS}

Nunung Kristiana, Risna Wijayanti and Djumilah Hadiwidjojo contributed to the design model and analysed the data of the research. Nunung Kristiana wrote the manuscript with input from all authors.

In addition, this research also contributes to the Covid-19 pandemic, because it helps companies make decisions regarding management strategies, especially in the area of increasing employee productivity, especially in this difficult time.

\section{ACKNOWLEDGMENTS}

We thank to PT. Pindad for supporting this study. This work was funded by PT. Pindad.

\section{REFERENCES}

[1] Zeglat, D., \& Suzi, J., Meaningful work and organizational outcomes: The mediating role of individual work performance. Management Research Review, $2019 . \quad$ DOI: https://doi.org/10.1108/MRR-05-2018-0206.

[2] CEIC, Labour Productivity Growth. 2020. [Online].

Available: https://www.ceicdata.com/en/indicator/indonesia labour-productivity-growth. Maret 2021.

[3] Movanita, A. N. K. Produktivitas Pekerja Indonesia Rendah. 2018. [Online]. Available: https://ekonomi.kompas.com/read/2018/07/29/0 64928426/produktivitas-pekerja-indonesiarendah-ini-penyebabnya?page=all. March 2021.

[4] Waldman, D. A., The Contributions of Total Quality Management to a Theory of Work Performance. The Academy of Management Review, Vol. 19, No. 3, Special Issue: "Total Quality" (Jul., 1994), pp. 510-536, 1994.

[5] Dale, B.G., Wu, P., Zairi, M., Williams, A.R. T., \& Van Der Wiele, T., Total quality management and theory: An exploratory study of contribution. Total Quality Management, vol.12, no. 4, pp. 439- 449, 2001.

[6] Noorliza, K., M. \& Asaari, H. A. H., The effects of total quality management practices on employees' work-related attitudes. The TQM Magazine, Vol. 18 Iss 1, pp. 30-43, 2006. DOI: http://dx.doi.org/10.1108/09544780610637677

[7] Iqbal, A., \& Muhammad Asrar-ul-Haq. Establishing relationship between TQM practices and employee performance: The mediating role of change readiness. International Journal of Production Economics 203, pp. 6268, 2018.

[8] Boon, O. K., \& Arumugam, V., HRM and TQM: association with job involvement. Personnel Review, Vol. 36 Iss 6, pp. 939 - 962, 2007.

[9] Minjoon, J., Cai, S., \& Shin, H., TQM practice in maquiladora: Antecedents of employee satisfaction and loyalty. Journal of Operations Management 24, pp. 791-812, 2006.

[10] Kabak, E. K., Sen, A., \& Gocer, K., Strategies for employee job satisfaction: A case of service sector. Procedia - Social and Behavioral Sciences 150, pp. 1167 - 1176, 2014.

[11] Shikdar, A. A., \& Das, B., The relationship between worker satisfaction and productivity in a repetitive industrial task. Applied Ergonomics 34, pp. 603-610, 2003.

[12] De Toni, Alberto F. International Operations Management. Routledge. New York, NY 10017, USA, 2016. 
[13] Ross, C., \& Al-Khawaldeh, K., TQM and labour productivity in Jordanian industrial companies. The TQM Magazine, Vol. 14 Iss 4 pp. $248-$ $262,2002$.

[14] Thiruchelvi, A., \& Palanichamy, Y. Does soft aspects of TQM influence job satisfaction and commitment? An empirical analysis. The TQM Journal, Vol. 29 Iss 2, 2017.

[15] Powell, T. C., Total Quality Management as Competitive Advantage: A Review and Empirical Study. Strategic Management Journal. vol. 16, no. 1 (Jan., 1995), pp. 15-37, 1995.

[16] Putri, N. T. T., Yusof, S. M., Hasan, A., \& Darma, H. S. A Structural Equation Model for Evaluating the Relationship between Total Quality Management and Employee Productivity. International Journal of Quality \& Reliability Management, 2017.

[17] Bari, M. W., Fanchen, Meng, \& Baloch, M. A. TQM Soft Practices and Job Satisfaction; Mediating Role of Relational Psychological Contract. Procedia - Social and Behavioral Sciences, vol. 235, pp. 453 - 462, 2016.

[18] Agu, A., \& Hassan Z. Enhancing Production erformance and Customer Performance Through Total Quality Management (TQM): Strategies For Competitive Advantage. Procedia Social and Behavioral Sciences, vol. 24, pp. 1650-1662, 2011.

[19] Choi, T., Karen, E. The TQM Paradox: Relations among TQM practices, plant performance, and customer satisfaction. Journal of Operations Management, vol. 17, pp. 59-75, 1998.

[20] Kazaz, A., Ulubeyli, S., \& Acikara, T., Er, B. Factor Affecting Labor Productivity: Prespective of Craft Workers. Procedia Engineering, vol. 164, pp. 28 - 34, 2016.

[21] Azadeh, A., \& Zarrin, M. An intelligent framework for productivity assessment and analysis of human resource from resilience engineering, motivational factors, HSE and ergonomics perspectives. Safety Science, vol. 89, pp. 55-71, 2016.

[22] Gerdenitsch, C., Sellitchs, D., \& Besser, M. Work gamification: Effects on enjoyment, productivity and the role of leadership. Electronic Commerce Research and Applications, vol. 43, pp. 100994, 2020.
[23] Koopmans, L., Bernaards, C., \& Stef van Buuren. Development of an individual work performance questionnaire. International Journal of Productivity and Performance Management, vol. 62 (1), pp. 6-28, 2012.

[24] Ugboro, I. O., \& Obeng, K, Top Management Leadership, employee empowerment, job satisfaction, and customer satisfaction in TQM organization: an empirical study. Journal of Quality Management, vol. 5, pp. 247 - 272, 2000.

[25] Habtoor, Nasser. Influence of human factors on organisational performance: quality improvement practices as a mediator variable. International Journal of Productivity and Performance Management, vol. 65 Iss 4, 2016.

[26] Jung, H., \& Yoon, H. Do employees' satisfied customers respond with a satisfactory relationship? The effects of employees' satisfaction on customers' satisfaction and loyalty in a family restaurant. International Journal of Hospitality Management, pp. 341-8. 2013.

[27] Roberts, J. A., \& David, M. E., Boss phubbing, trust, job satisfaction and employee performance. Personality and Individual Differences, vol. 155, pp. 109702, 2020.

[28] Ghozali, I. Structural equation modeling: Metode alternatif dengan partial least square (Keempat). Semarang: Badan Penerbit Universitas Diponegoro, 2014.

[29] Hair, J. F., M.Hult, G. T., M.Ringle, C., \& Sarstedt, M., A primer on partial least squares structural equation modeling (PLSSEM) (2nd Ed). Los Angeles: SAGE Publications, Inc, 2017.

[30] Abdillah, W., \& Hartono, J., Partial Least Square (PLS). Alternatif Structural Equation Modelling (SEM) dalam Penelitian Bisnis. Yogyakarta. C.V. Andi Offset. 2015

[31] Hair, J. F., Ringle, C. M., \& Sarstedt, M., Editorial Partial Least Square Structural Equation Modeling: Rigorous Applications, Better Results and Higher Acceptance. ELSEVIER, pp. 1-12, 2013.

[32] Ahmed, O. A., \& Idris, A.A. Examining the relationship between soft total quality management (TQM) aspects and employees' job satisfaction in "ISO 9001" Sudanese oil companies. The TQM Journal, pp. 1754-273, 2020. 